\title{
A személyiség varázsa
}

\author{
Kissné Novák Éva \\ Mottó: „Az ember amióta csak létezik, látványul \\ kínálkozik önmagának. Évezredek óta \\ valóban nem is szemlél mást, mint önmagát." \\ Teilhard de Chardin
}

Heidegger gyönyörü kifejezését használva mondhatjuk, hogy az ember a „lét pásztora”. Mit is jelent ez a kifejezés? A pásztor gondoskodik a rábízott állatokról. Az ember gondoskodik a hozzá hasonlóan a világba belevetettként élőkröl illetve létezőkről. Gondoskodik önmagáról megteremtve, megformálva és megvédve saját egzisztenciáját, saját életét és személyiségét. Gondoskodik a körülötte élőkről: családjáról, barátjáról, kollegáiról, ismerőseiről, tanítványairól, sőt valamilyen tág értelemben arról az adott közösségröl, melynek tagjaként létezik. De gondoskodik a létezők olyan csoportjairól is, melyek nem vagy csak korlátozott mértékben képesek önmagukról gondoskodni: a bennünket körülvevő növényekről, állatokról, egyszerüen fogalmazva természeti környezetünkröl, sőt a tárgyi világról is, amely fontos keretét alkotja mindennapi életünknek. A gondoskodás módja, tartalma és formája természetesen más - más minden esetben. Másként gondoskodunk a kutyánkról, mint a szobában álló növényeinkröl, másként a kedves könyveinkröl vagy íróasztalunkról, és másként a kiskorú vagy már felnőtt gyermekünkről, és megint másként az ismerős szomszédról vagy barátról. Ám mindegyik formájában a gondoskodásnak van egy közös elem: a lét számunkra megnyilvánuló összetevőiről, azaz a velünk együtt létezőkről igyekszünk gondoskodni, azokról a személyekről és dolgokról, melyek hozzá tartoznak életünkhöz, akiket, és amiket létünk szerves tartozékainak, mintegy létünk meghosszabbításának érzünk. A hozzájuk füződő kapcsolatainkban mi vagyunk jelen, magunkat vetítjük ki, s ez a kapcsolat beépül személyiségünkbe.

Előadásomban arról szeretnék beszélni, hogy miből is áll elő az a különös entitás, az a sajátos lényeg, amit személyiségünknek nevezünk.

Én úgy fogalmaznám, hogy mindnyájan készen kapunk születésünk pillanatában egy un. genetikai apriorit és egy szociális apriorit. Genetikai apriori alatt értem fizikai alkatunkat, 
szemünk színét, arcvonásainkat, de ide tartozik temperamentumunk, gyors vagy éppen lassú felfogóképességünk, érzékenységünk stb., tehát csupa olyan vonás, amely lényegében születésünk pillanatában kódolva van. Ezekről az öröklött képességekről nem szólok. Ezen a területen még mindig nagyon sok a megválaszolatlan kérdés. Tudjuk, hogy bizonyos tehetségek olykor öröklődnek, erről tanúskodnak pl. a zenészdinasztiák (pl. A Bach család vagy a Stauss familia), vagy az Erdélyből származó Benedek család ( Benedek Elek a híres mesemondó és író, fia Benedek Marcell kitünő esztéta és maga is író, és az ő fia Benedek István, aki agykutató, de íróként is ismert és kedvelt). Ugyanakkor tudjuk, hogy kitűnő tehetségek születtek átlagos képességü szülőpártól, vagy épp ellenkezőleg: nagyon tehetséges szülök képességei nem folytatódtak a gyermekekben. Nem is az én kompetenciám ez a terület.

A szociális apriori kifejezés pedig azt a társadalmi szituációt foglalja össze egyetlen fogalomba, amelybe beleszületünk: a kort, a nemzetet, egy kisebbséget, egy társadalmi csoportot, esetleg egy vallási közösséget, melyeket általában a szülői család jelent.

Személyiségünket tekintve mindkettő véletlen, hiszen nem tehetünk arról, hogy mit öröklünk elődeinktől akár külső, akár belső tulajdonságként, miként arról sem, hogy milyen családba születünk bele. De valamennyien tudjuk, hogy kialakuló, formálódó személyiségünk attól függ, hogy ezt a két adottságot miként tudjuk egységgé formálni. Ki tudjuk-e használni az egyikben vagy másikban rejlő lehetőségeket, van-e bennünk elég akarat a bennünk lévő talentum kibontására, vagy könnyelmüen veszni hagyjuk a természet vagy a jó Isten ajándékát. S az sem mindegy, hogy a családi vagy tágabb környezet képes-e, akar-e segíteni bennünket ezen az úton. Ezért nem tudom maradéktalanul elfogadni a marxizmus felfogását, amely máig érvényesül pedagógiai nézeteinkben - mely szerint föként a társadalmi környezet felelős az egyén fejlődéséért, s reménykedik abban, hogy hatékony pedagógiai módszerekkel mindenkiből „kivarázsolható” az egyenlőség eszményének megfelelő emberke. Ez Marx nézeteinek súlyos félreértelmezése. Marx arról beszél, hogy az ember univerzális lény, és emberként egyenlő, de szó nincs arról, hogy a képességek tekintetében egyenlőnek tételezné az embert. De nem tudom helyeselni az egzisztencializmus álláspontját sem, amely viszont minden felelősséget az emberi akaratra, erőfeszítésre hárít. „Az ember nem más, mint tetteinek a sora” - fogalmaz Sartre. „Az ember szabadságra ítéltetett” - írja. ${ }^{1}$ A szabadság valóban együtt jár a felelősséggel, így a tehetségünkért viselt felelősséggel is, de nem hagyható figyelmen kívül az a körülmény, hogy milyen tényezők akadályoznak, korlátoznak vagy segítenek bennünket.

Az ember személyiségének lényegét sokan próbálták megfejteni. Többen modellezték a személyiség szerkezetét, kutatták az öröklött és szerzett tulajdonságok viszonyát, arányát, 
elemezték a különböző közösségek és az egyén kapcsolatát, és ennek hatását a személyiség változására. Vizsgálták azt a folyamatot csecsemő kortól a felnőtté válásig, amelynek révén kialakul az ember személyisége, és fontos következtetésekre jutottak: tudjuk, hogy mely periódusok a legjelentősebbek a személyiség formálódása szempontjából, tudjuk, hogy igen fontos különbségek léteznek az egyes egyének között a szocializáció módszereit, hatékonyságát tekintve, tudjuk kik az un. vonatkoztatási személyek, akiknek meghatározó szerepük van a gyermek fejlődésében. Előadásomban erről az utóbbi kérdésről szeretnék beszélni.

Minden személyiségelmélettel foglalkozó mű hangsúlyozza, hogy meghatározó szerepe van a személyiség fejlődésében az első impulzusoknak, s ezeket a gyermek elsősorban a családtól, főként az édesanyától kapja. A család két szempontból is kitüntetett pozíciót foglal el:

- a gyermek élete első 6 évében a legfogékonyabb minden érzelmi és értelmi hatásra, és nagyon jól megfigyeli és megőrzi a látott mintákat. Itt tehát egy életre szóló muníciót kap pozitív és negatív értelemben egyaránt.

- Az un. családi szerepeket - miként kell nőnek és férfinek, férjnek és feleségnek, anyának és apának lenni - elsősorban itt tanulhatja meg.

Ahogyan Sütő András fogalmazta:” A család...sorsot formáló - legalábbis meghatározó mindnyájunk számára. E földi vándorúton ama bizonyos hamuban sült pogácsa: a család. Jó szava, szelleme, védőszentje a mesebeli hősnek....A család az, ahol zúzmarás időkben titkon ünnepelhető a titok: az együvé tartozás tudata."2

A család mellett a szocializáció folyamatában fontos, meghatározó tényező a társadalom maga normáival, elvárásaival, értékeivel, vagy éppen értékzavaraival; a település, ahol élünk; minden közösség, ahová hosszabb-rövidebb ideig tartozunk sportkörtől az énekkarig. Fontos szerepet játszanak a kortárs csoportok (pl. serdülőkorban a legfontosabb); fontos determináns tovább a média, mert rendkívüli hatékonysággal erőlteti ránk a maga mintáit, és természetesen minden olyan intézmény, amit erre a célra hoztak létre. Az óvodától az egyetemekig bezárólag minden oktatási intézmény ide sorolható. Ezekben a vonatkoztatási személy a óvónő illetve a tanító néni vagy bácsi, majd később a tanárnő vagy tanár úr.

A gyakorló szülők maguk is tudják, hogy milyen lényeges szerepe van a tanárnak a gyermek személyiségének alakulásában. A jó tanár megkedvelteti a gyermekkel a tanulást, mert megismerteti vele a tudás örömét. Közel hozza gondolkodásához az általa tanított ismeretrendszert. Megszeretteti, de legalábbis elfogadtatja vele az iskolát rendszabályaival együtt, felmutatva annak életszerüségét, „felnőttes” jellegét. Megérteti a közösség támogató 
és kontrolláló szerepét. A felsorolást még folytathatnám, de talán szükségtelen. Akik itt ülünk mindnyájan tudjuk, hogy a mögött az egyszerü kijelentő mondat mögött, hogy ,a tanár tanít és nevel" felsorolhatatlanul sok tevékenység van. S úgy vélem, ez mai korunkra fokozottan érvényes. A családok nem kicsiny része ugyanis, a megváltozott élettempó, a nálunk jellemző kétkeresős családmodell, a nők kereső munkája, karrierépítése miatt kevésbé tudja ellátni azokat a feladatokat, amelyek révén gyerekeink a siker reményében indulhatnának az iskolába és az un. Életbe. S akkor még nem beszéltünk az elvált családok miatt nehéz helyzetbe került gyerekekröl, a különböző devianciákról (drog, alkohol, bünözés stb.) Az iskolának és a tanárnak a fenti okok miatt megnövekszik a jelentősége és szerepe.

A személyiségnek minden emberi kapcsolatban meghatározó szerepe van. Többkevesebb tudatossággal erre figyelünk, amikor az iskolában kiszemeljük a padtársunkat, amikor barátot, barátnőt választunk és különösen fontos, amikor életre szóló kapcsolathoz keressük a megfelelö személyt. De még kollegaként is fontos, hogy milyen a velünk együtt dolgozók személyisége: toleráns, vagy agresszív, segítőkész vagy elutasító, barátságos vagy rideg stb. Van azonban néhány olyan foglalkozás, hivatás, amelyben fokozott jelentősége van a személyiségnek. A teljesség igénye nélkül ilyen pl. az ügyvéd, a pap, a színész, a pszichiáter és természetesen a tanár.

Tekintsünk először az oktatott tárgyra! Az igazi tanár számára az ismereteknek az a területe, amit ő tanít, nem egyszerüen egy tantárgy, amit kötelezően tanulni kell, hanem a valóságról szóló információk érdekes és hasznos halmaza, amit érdemes tudni. Úgy vélem, mindegy mi a tanított tárgy, ha tanár azon keresztül ablakot nyit a világra, s megmutatja azokat a titkokat, melyek érdekessé teszik az általa tanított témát. A kémia nem tartozott az engem mélyen érdeklő témák közé, de olyan tanárom volt középiskolában, aki úgy tudta elmondani, pl. a Mengyelejev féle periódusos rendszer lényegét, hogy elbüvölt bennünket az a tudományos előrelátás, amellyel évszázadra előre megmondta egy tudós, hogy a hiányzó helyekre még milyen elemeket kell meglelni a valóságban. Felnőttként is gyakran elgondolkodom, hogy milyen fantasztikus, hogy valaki így belelát a természet titkaiba. Ehhez természetesen alapfeltétel, hogy a tanár maga magas szintü tudás birtokában legyen, hogy higgyen a tudás fontosságában, hogy tájékozódjék tudományterülete újabb eredményei felöl, röviden úgy fogalmaznám, hogy meggyőző tudással rendelkezzen. Fontos azonban, hogy a fölényes tudás ne párosuljon fölényes magatartással. Ugyanis a mai technika, a média házhoz szállítja a legújabb információkat, s az interneten böngésző diák találhat olyan témákat, amelyekkel úgymond meg lehet fogni a tanárt. Nem az apró részletek ismeretével lehet kivívni a diák elismerését elsősorban, hanem az összefüggések feltárásával és a tudás 
tiszteletével - beleértve a diák tudásának tiszteletét is. Fogalmazhatjuk úgy, hogy a jó tanár olyan mint a jó kertész, aki gondosan elveti a magokat, és megtesz mindent a bő termés érdekébe: naponta gondozza, ápolja. Persze tudjuk, hogy ebben az esetben a „talajt” nem ő egyedül készíti elő, hiszen a diák már bizonyos tapasztalattal került hozzá, amelyek sajnos nem is mindig kedvezőek.

Itt szeretném röviden jelezni azt a kényszerhelyzetet, ami Magyarországon az ötvenes hatvanas évektől kezdődően a hetvenes évek végéig létezett. Köztudott, hogy a szocializmus fontos feladatának tekintette az analfabétizmus felszámolását, az ismeretek terjesztését. Ennek érdekében kötelezővé tette a 8 általános iskola elvégzését. Ehhez azonban nem volt az országban elegendő szakképzett pedagógus. Ebben a szituációban született egy olyan döntés, hogy érettségi után azok a fiatalok, akik pedagógus pályára készülnek és felvételt nyertek valamelyik felsőoktatási intézménybe levelező tagozatra, azok azonnal taníthatnak általános iskolában. Ez a mintegy két évtizeden keresztül fennálló rendszer nagyon sokat ártott a pedagóguspálya presztizsének. Ezeket a tanárokat hivatalosan is képesítés nélküli pedagógusnak nevezték. Némi malíciával mondhatom, hogy nem ismerünk képesítés nélküli cipészt, pedig van különbség aközött, hogy a törött sarkú cipőmet vagy a gyermekemet bízom valakire. Ezek az abszolút pályakezdök gyakran mindössze néhány lépéssel jártak az anyagban a diák előtt. Tiszteltet érdemel az az erőfeszítés, amivel igyekeztek eleget tenni tanítási feladataiknak éppúgy, mint az adott föiskola követelményeinek, de tárgyilagosan meg kell állapítani, hogy csak keveseknek sikerült magas színvonalú tudást szerezni ebben a kettős szorításban. Többségük kisebb falusi iskolákban tanított, ahol a szülök és a gyerekek is úgy tekintettek rájuk, mint közülük való diákra, aki épp csak idősebb néhány évvel. Ebben a légkörben nagyon nehéz is lehetett megszerezni a tanárt megillető tekintélyt. Ezekböl a falusi iskolákból rekrutálódott a frissen alakult sok új középiskola diáksága. Egyfelől örömteli eredménynek látszott, hogy nő a középiskolát végezettek aránya a népességen belül (ezt a hivatalos politika boldogan hangsúlyozta is), másfelől látni kell, hogy az újonnan alakult iskolák egy jelentékeny része nem tudott odavonzani olyan pedagógusokat, akik versenyképessé tehették volna a gimnáziumot vagy technikumot a régebbi tradíciókkal, hírnévvel rendelkező iskolákkal szemben. A demográfiai hullám tetején az ún. jobb iskolák (már az általános iskolák is ) válogattak a gyerekek közül, s csak a legjobb képességüeket vették fel. A válogatás természetesen nemcsak a gyerekekre, hanem az állást kereső pedagógusokra is vonatkozott. Egy-egy jobb iskolába bejutni komoly szakmai ambíciókkal is igen nehéz volt. Innen nézve érthető, hogy ma látványos különbség van a kisebb települések 
iskoláiban végzett gyerekek tudása, felkészültsége és egy jobb városi iskola tanulóinak tudása között. Ez a távolság a rendszerváltás óta - sok ok együttes következményeként még nőtt. Mai ,,illúzióink” közé tartozik az az elképzelés, hogy a modern technika, az Internet, amit a laptopon oda lehet varázsolni, az interaktív tábla és más hasonló „,csodák” javíthatnak a helyzeten. Ilyen kísérletekről lelkendező hangú cikkekben számolnak be az újságok. ${ }^{3}$ Nem vitatom, hogy a diák számára érdekes lehet ezekkel a technikai csodákkal való bíbelődés, de komolyan kételkedem abban, hogy ettől hatékonyabban tanulnának. Vitathatatlan, hogy bizonyos tárgyakat, pl. a nyelvtanulást eredményesen segítheti, illetve a tanár ellenőrző munkáját megkönnyíti a számítókép, a nyelvi labor. Ahhoz azonban, hogy a diák ne csak a hálón kikeresni tudja a helyes válaszokat, hanem meg is tanulja azokat, ahhoz megítélésem szerint elengedhetetlen a tanári minta vonzása, amely tartós ismeretek megszerzésére inspirál. Még egy súlyos aggályom szeretném megosztani a tisztelt hallgatósággal. A laptopon kitöltött tesztek talán jelzik a megszerzett tudást, de nem tesznek alkalmassá arra, hogy azt szóban vagy írásban elő is adják. Szomorú tapasztalatom, hogy egyetemi hallgatóink között - pedig ők alkotják a korosztályuk színe - javát - nagyon sokan nem tudják szóban korrekt módon, helyes magyarsággal megfogalmazni a gondolataikat. Az esszé típusú írásos dolgozatok tanúsága szerint írásban sem. Tegyük fel a kérdést: milyen értelmiségi lesz az, bármilyen pályán is dolgozzon majd, aki nem tud anyanyelvén jól kommunikálni? Képes-e megtanulni helyesen valamilyen idegen nyelvet, ha az anyanyelvét is hibásan beszéli, írja? Ezek mögött a kérdések mögött azt a folyamatot kell látni, amely évek óta jellemző - tudomásom szerint nemcsak a magyar iskolákra - amely tesztkérdések bekarikázására egyszerüsítette a tudás mérését, s amely most tovább kíván lépni ezen az úton; a tanárt szinte kihagyhatónak gondolva az oktatás folyamatából. Mintha a tanár csupán szervezője lenne az egésznek. A technika használatán túl meg kell tanítani a diákokat az önálló gondolkodásmódra, az együttmüködésre és a függetlenségre éppúgy mint az idővel való helyes gazdálkodásra, a koncentrációra, és arra is, hogy mi a siker. Ebben a meglehetősen ellentmondásos világban el kell(ene) érni, hogy a gyerekek ne veszítsék el a tanulásba, tudásba vetett hitüket. Ehhez viszont elengedhetetlen az a tanár, aki figyel a gyerek magatartására, belső reakcióira és körülményeire, aki tudja, mert ismeri a tanítványát, hogy mennyi erőfeszítés van az adott eredmény mögött, hogy miként kell ösztönözni a jó tanulót, és miként kell segíteni a problémás gyereket. (Őze Lajos kitünő színészünk példáját említeném, akit a dadogó beszédből az ő türelmes és figyelmes tanítója „,gyógyított” ki.) 
Még nagyobb szükség van a tanár hatékony példájára és tevékenységére a gyermek személyiségfejlődése szempontjából. Mint már jeleztük, modern korunk új kihívásokkal szembesítette a családokat és bennük természetesen a gyermekeket is. A magyar szülök jelentékeny része egyszerre kíván megfelelni a munkahely, a szakma, a hivatás elvárásainak és a családi (férj, feleség, apa, anya stb.) feladatainak. Mivel a megélhetési kényszer a munkát teszi első helyre - mind a férfiak, mind a nők esetében - a családi tennivalók kisebb hangsúlyt kapnak, vagy éppen háttérbe szorulnak. Ma Magyarországon a gyerekek igen kicsiny hányadát várja otthon az édesanya ebéddel, gyakorta reggel is egyedül indul a gyerek iskolába. A munkahelyek teljes értékü munkát várnak el mindkét nemtől, és tényként állapíthatjuk meg, hogy a nők is mind magasabb számban tudatosan építik karrierjüket. Ezen tendenciák találkozásának a gyermek a fó vesztese. Viszonylag kevesen tudják megfizetni a szolgáltatásokat, így a családok döntő többsége maga főz, mos, takarít stb. Mindezek következménye, hogy a felmérések tanúsága szerint az átlag magyar család naponta 2,5 - 3 percet beszélget a gyermekével. A számadatot nem kívánom kommentálni. Világos, hogy az iskoláskorú gyermekkel való törődés jó esetben a „kész van a leckéd?” címü kérdésre szorítkozik. Így fordulhat elő, hogy a kábítószerező gyerekre olykor előbb figyel fel az iskolaorvos, a pedagógus, mint a saját szülöje.

Az elmondottak nem egy vádiratba készültek magyar szülőkkel szemben, hisz tudjuk, hogy igen sokukat a megélhetésért, a gyermek igényeinek kielégítéséért való munka köti le. Csak arra szerettem volna rávilágítani, hogy egy ilyen helyzetben hatványozottan szükség van a tanárra, aki nemcsak tanít, de emberségből példát is mutathat nekik. Éppen ezért a tanár szerepe felértékelődik.

A minta, amit mutat(hat) nagyon sokrétü. Mindenek elött a tudáshoz való viszonya lehet példa értékü. Ha a diákok azt tapasztalják, hogy óráról órára felkészülten érkezik, jó órákat tart, nem rutinból tanít, megújuló ötletekkel teszi érdekesebbé, tanulhatóbbá az adott témát, szavak nélkül is megértik, hogy bármi legyen is a foglalkozásunk, azt csak egy szakmai elkötelezettséggel lehet jól végezni.

Természetesen a tanítványokhoz való viszonya, a problémák kezelése is minta lehet a környezet számára. Az a tanár, aki figyelmével tiszteli meg a diákot, maga is számíthat hasonló magatartásra. A probléma iránti érzékenysége, megértése, toleranciája lehet, hogy olyan hiányértéket mutat a gyerek számára, amivel addig nem találkozott. Erőszakkal telített világunkban nagyon fontos minta lehet a konfliktusok tárgyalások útján történő elsimítása, megoldása. Hosszan lehetne beszélni - és talán kellene is, de az egy másik előadás lenne- a média hatásáról, amely már a gyermekmüsorokban is erőszakkal, agresszióval telített. S mivel 
a gyermek sajnos gyakorta otthon is látója, résztvevője, vagy elszenvedője különböző erőszakos jeleneteknek (rosszabb esetben cselekedeteknek) nem meglepő, hogy maga is ezt a látott mintát követi. Azt mondhatjuk az iskolarendszer szinte az egyetlen helyszín, ahol toleranciát, együttmüködést tanulhat, s mivel ezt egy kortárs közösség keretei között teheti egy tanár segítségével, vagy irányításával eredményes is lehet. Ilyen helyzetekben rendkívüli jelentősége van a tanár személyiségének, elsősorban érzelmi intelligenciájának. Erről a nagyon fontos képességről viszonylag ritkán beszélünk, pedig az önmagunkkal és másokkal való báni tudás az egyik legfontosabb eleme személyiségünknek. Az önismeretre, helyes önértékelésre, önkontrollra építő empátia, intuíció, kapcsolatteremtő képesség, meggyőző erő (nemcsak) a tanár legfontosabb eszköze. Ezen múlik, hogy megtalálja-e a megfelelö mondatokat, példákat, melyek elindíthatnak egy kedvező folyamatot - esetleg nemcsak a problémás - gyermek lelkében.

(Levelezős hallgatóm mondta el azt a történetet, amelynek szereplöje egy nagyothalló kislány, aki normál osztályba került. A tanárnő megkérte az egyik jól tanuló diákot, hogy segítsen neki, ha rászorul. Egy idő után a mellette ülő társat idegesítette nagyothalló osztálytársa, és kérte, hogy ültessék máshová. De senki nem akart a padtársa és segítője lenni. A tanárnő másnak egy csomag vattával jelent meg, és utasította az osztályt, hogy mindenki dugja be a fülét, majd magyarázni kezdett. Az osztály néhány pillanat alatt átélte és megérezte azt a hiányt, amivel társuknak folyamatosan együtt kell élnie, és azóta felváltva segítik a nagyothalló kislányt.)

Minta lehet tovább a tanár és kollegái viszonya. Nem ritka, hogy a tanár megfeledkezik a „mundér becsületéről”. A kollega kritizálása a hallgatók előtt talán az érintett diákban a beavatottság érzetét kelti pillanatnyilag, de elgondolkodva a történteken biztosan levonja a megfelelő konzekvenciát. Nemcsak kollegalitásból, de loyalitásból és emberségből is elégtelenre vizsgázik az ilyen tanár.

Gyakorta előfordul, hogy az legalapvetőbb szerepeink tekintetétben is - a férfi és a nő szerepére gondolok - mintára szorulunk. Attól, hogy egy adott nemhez tartozónak születünk, még nem magától értetődő, hogy miként kell egy Nőnek és egy Férfinek (szándékosan nagybetűvel írom és mondom) viselkednie. Ez különösen akkor okozhat súlyos problémákat, ha elvált szülők gyermekeként cseperedik a tanítványunk. Bármelyik szülői minta is hiányzik mindkét nemü gyermeket megviseli. A fiúknak különösen hiányzik az apa-minta, de a lányok szocializációja is kissé féloldalas lehet a férfi minta hiányában. E tétel igazságát számos szociológiai vizsgálat igazolja, és néhány országban pl. Kanadában érdekes, egyenlőre kísérletként értelmezhető módszerrel igyekeznek segíteni az ilyen problémával küzdő 
gyermekeknek. A módszer neve: big Brother. Ebből a nézőpontból tartom sajnálatosnak a tanári pálya elnőiesedését. Tanítani bármely tárgyat természetesen egy nő is éppoly jól tud, mint egy férfi. De férfi mintát csak a tanár úr mutathat, s ebböl sajnos kevés van az általános és középiskolákban.

Visszagondolva az elmondottakra fogalmazhatunk úgy, hogy a személyiség egyrészt viszonyok rendszere. Mindazok a kapcsolatok, melyekbe beleszületünk illetve, amelyeket magunk teremtünk meg, építünk fel környezetünk és önmagunk között, beépülnek személyiségünkbe. Ezek következtében leszünk barátságos, kedves, toleráns, állatbarát, környezetvédő stb. emberek, vagy éppen ennek az ellenkezői. A viszonyok egy jelentős részét készen kapjuk, ebbe a tanár sem tud segítő módon beavatkozni. Nem adhat nekünk jobb, kedvesebb, felelősségteljesebb szülőt. De azokban a kapcsolatokban, melyeket már magunk alakítunk ki, adhat tanácsot, segíthet dönteni, hogy ne méltatlan személyekre, dolgokra, viszonyokra fecséreljük szeretetenergiánkat.

Másrészt igaz, hogy a személyiség szerepek rendszereként müködik. E tekintetben is nagyon fontos szerepe van a tanár egyéniségének. Felmutat szerepmintákat, segít értelmezni a szerep belső tartalmát (mit jelent férfinek, nőnek, tanárnak, vezetőnek, apának stb. lenni), felhívja figyelmünket a szerepválasztás fontosságára, az esetleges szerep kolliziókra. Segít megérteni a felnőtt világ problémáit, a szerepekkel együtt járó felelősséget. Személyes tapasztalataim mutatják, hogy erre nemcsak általános és középiskolás korban, de a felnőtt kor küszöbén is nagy szükség van. Gyakori élményem, hogy hallgatóink magas szintü tudással rendelkeznek, profi módon kezelik a számítógépet, nyelveket beszélnek, de az élet kis és nagyobb dolgaiban kevéssé felkészültek.

Harmadrészt a személyiség értékorientációk rendszere. Én úgy szoktam fogalmazni, hogy értékeink alkotják lelki csontvázunkat, s így természetesen személyiségünk lényegét is. Az értéktanulás folyamatában, az értékek internalizálásában - azaz belsővé, magunkévá tételében - kitüntetett szerepe van a tanárnak és személyiségének. Bár az értékek elsajátítása a látott minták alapján már kicsiny gyermekkorban elkezdődik, de a tudatosulás, a minta tudatos utánzása, követése vagy épp elutasítása az iskolás évekre esik. A tanárnak lehetősége, módja van a már megtanult minták megerősítésére, vagy gyengítésére, ha azok hibás magatartást jelentenek. Nagy tapintattal még a szülőktől látott rossz mintákra is felhívhatja a figyelmet. Gyakran elhangzik az érv, hogy a modern társadalmakban a gyerekek (és természetesen a felnőttek is ) rengeteg időt töltenek a TV előtt. A tények makacs dolgok, ezt az állítást nem lehet vitatani. De mai iskolarendszerünk követelményei folytán a gyerekek napi 6-8 órát 
töltenek az iskolákban is, talán ezt az időt is ki lehetne, sőt ki kellene jobban használni személyiségük formálása érdekében.

Tisztában vagyok vele, hogy súlyos feladatot fogalmaztam meg. Azt is tudom, hogy ez a tennivaló mindig nehéz és sokszor hálátlan terület volt. De korunk tényeinek ismeretében melyekről részben szóltunk csak - az egyetlen intézmény az iskolarendszer és benne a felkészült tanár, akitől a jövő generációjának formálását a közös bölcsesség elveinek megfelelően remélhetjük. A szülőket csak sok áttételen keresztül próbálhatjuk befolyásolni , jobb, okosabb felnőtté, szülővé tenni. De a tanítványaink még figyelnek ránk. S a tanított ismeretek számtalan esélyt kínálnak fontos értékek felmutatására. Az emberi akaraterő, egy jó ügy iránti elkötelezettség, és egyúttal pl. a szabadság értékének nemzetközi voltát lehet felmutatni az aradi 13 vértanú megrendítő történetében. Egy szép, szerelmes vers kitünő alkalmat kínál arra, hogy felmutassuk az igazi szerelem csodáját és azt a különbséget, amely a futó kíváncsiság és az üres testi vágy valamint a valódi szerelem között van. Széchenyi példáján bemutatni a hangzatos szavakban és a tettekben testet öltő hazafiság közötti különbséget. Az elveink melletti kiállás nagyszerüségét, pl. Giordano Bruno példáján. Nem folytatom a példák sorát, bizonyára mindenki hozzá tudna tenni jó néhányat. Az írástudó felelőssége a tanár nehéz, de nagyon szép terhe. Olyan teher, amit csak méltósággal, szeretettel lehet viselni. Tudni kell, hogy a tanár (egyik) legfontosabb eszköze az ő személyisége. Személyiségének varázsa az, amely segíti a tanítványait abban, hogy minden gyerek az ő „legsajátabb - lenni -tudásá”-ból a legtöbbet valósítsa meg.

0

\footnotetext{
1 Sartre: Lét és Semmi

${ }^{2}$ Sütő András, idézi Neményi Mária: A család Budapest, Gondolat K. 1988 23-24.o.

${ }^{3}$ Népszabadság 2008.január 26. Virtuális séta a Louvre-ban
} 